\title{
Compliance of Micro Small Medium Enterprise Tax Payers To Gross Regional Domestic Product
}

\author{
Yuli Nawangsasi ${ }^{1}$, Inayati Nasrudin ${ }^{2}$, Hida Purnamawati ${ }^{1}$ \\ Program Studi Manajemen, Universitas Sangga Buana, Bandung, Indonesia ${ }^{1}$ \\ Program Studi Manajemen, Universitas Sangga Buana, Bandung, Indonesia ${ }^{2}$ \\ Program Studi Manajemen, Universitas Sangga Buana, Bandung, Indonesia ${ }^{3}$
}

\begin{abstract}
Increasing the number of Micro Small and Medium Enterprise local government of Bandung is a potential source of income from the local tax sector to increase development an economic city of Bandung. This research is to describe the role of tax payer compliance rate on Micro Small and Medium Enterprise to increase the Gross Regional Domestic Product as measured by the increase government expenditures of finance development of Bandung city during period 2013 2016. The method of study is descriptive verificatif by using the analytical tool Two Stage Least Square. The result of the analysis indicates that compliance of micro enterprise tax payers will impact to increase the gross regional domestic product through the increased government expenditures sourced from local tax revenues
\end{abstract}

Keyword. tax payer compliance; micro small and medium enterprise; gross regional domestic product; government expenditures.

Article history. Received Agustus, 2018. Revised Oktober, 2018.Accepted December, 2018

Corresponding author. Email. nawangsasi_yuli@yahoo.com

How to cite article. Nawangsasi, Y., Nasrudin, I., \& Purnamawati, H. (2018). Compliance of Micro Small Medium Enterprise Tax Payers To Gross Regional Domestic Product. The International Journal of Business Review (The Jobs Review), 1(2), 85-92. https://doi.org/https://doi.org/10.17509/tjr.v1i2.12885

\section{INTRODUCTION}

Increasing the number of Micro Small and Medium Enterprise (MSMEs) local government of Bandung is a potential source of the revenue from the local tax sector to improve the development and economy of Bandung. Nining Sudiyarti, el al (2017), in her research stated that, Micro Small and Medium Enterprise have a significant effect on economic growth. Thus, the taxpayer compliance rate of a micro enterprise paying taxes is crucial in determining an increase in the gross regional domestic product to measure the success rate of the economic development of a region. MSMEs tax revenue in Bandung is a source of the regional revenue was derived from the revenue-sharing funds contained in the regional revenue and expenditure budget allocated by the central government to regions based on the percentage figures to fund regional needs in the context of implementing decentralization. From the results of research by Darmayuda, et al.(2009), was states that the tax revenue significantly affects the Gross Regional Domestic Product of districts / cities in North Sumatra. With the increase of PDRB Bandung was expected an increase in local government expenditure in terms of empowerment and improve performance for the welfare of micro small medium enterprises. The results of the study by Magdalena, et al,(2016), was 
stated that empowerment and the performance of MSMEs had a positive and significant effect on the welfare of MSMEs players.

The government has established Government Regulation No. 46 of 2013 which is intended for MSMEs. The Government Regulation provides convenience and awareness to carry out its tax obligations. This Government Regulation can indirectly improve taxpayer compliance, so that tax revenue from their enterprises has contributed to the improvement of the economy both nationally and regionally. However, the development of this small and medium-sized enterprise, has not yet reached the target of compliance ratio to pay taxes that have been set by the government through the Directorate General of Tax Circular. While tax revenue as a tax object, each year increased significantly.

The Gross Regional Domestic Product (GRDP) in this study was examined from the approach of calculating expenditure approach, with the PDRB $=\mathrm{C}+\mathrm{I}+\mathrm{G}+(\mathrm{X}-\mathrm{M})$ equation. Where household sector expenditure is public consumption (C), enterprise sector expenditure is an investment (I), government expenditure (G), while foreign trade expenditure is reflected in the difference between the export and import of the country concerned (X - M ). (Roger E., 2015). The increase in GRDP component will increase GRDP through the multiplier effect of each of these components. The $G$ factor (government expenditure) in this study is the main focus. Increased local government spending is unlikely to occur if local government revenues do not increase. Therefore, an increase in government revenues, especially from the tax sector is very necessary. One of the efforts made by the government is to collect income tax on MSMEs in the hope of contributing to increase government revenue. This increase will increase by regional government spending. through the allocation of revenue-sharing funds from the central government to the regions that will ultimately increase the GRDP through the multiplier effects of the local government expenditures.

The previous research that has been described above has not been examined from the factor of the local government expenditure which is the measure from the GRDP increased. Therefore, the link between MSMEs income tax and regional revenue is important to be examined to give an idea from the contribution of MSMEs income tax to GRDP. It is expected that through this research, it can get a picture of the taxpayer compliance the MSMEs which have implication to the increase of GRDP as measured from the increase of local government expenditure to finance development in Bandung, especially to improve the prosperity of small and medium enterprise actors sourced from tax-sharing fund. The model analysis of this research was use the regression method with a two-stage approach (Two Stage Least Square), (Wooldridge, JM, 2010), because to estimate the equation of influence of MSMEs Taxpayers Compliance to the ratio between income tax with the local tax revenue and to estimate the regression result forecasting variable the local tax revenues that have been influenced by the compliance of MSMEs taxpayers to local government expenditure.

\section{METHOD}

This research uses descriptive verification method. In this case, the variable compliance rate of the MSMEs taxpayer to the ratio between the income of MSMEs income tax with local tax revenue and the variable of local tax revenue already influenced by the compliance of the MSMEs taxpayer to the local government expenditure. Theoretical framework of thought shows that taxpayer compliance indirectly affects the GRDP, but through local revenue derived from local taxes. Therefore, the model of analysis method was used is the regression method with the two-stage approach (Two Stage Least Square), (Wooldridge, J. M. 2010), as follows: 
The first stage, to estimate the equation of influence of taxpayer compliance of MSMEs to the ratio between income tax of MSMEs with local tax revenue, with model of regression equation below:

Where :

$$
S P D_{t}=\alpha+\beta K W P_{t}+\varepsilon
$$

SPD = Ratio of the tax revenue MSMEs to totally local tax revenue Bandung KWP = MSMEs Taxpayer Compliance which is measured by the ratio between the mandatory amount MSMEs Payments are paid. and its registered.

$\varepsilon=$ error term

The second step is to estimate the regression of the forecasting result ratio between income tax receipts and total local tax revenue $\left(\widehat{S P D_{t}}\right)$ on government expenditure $(P P)$, which is stated in equation below:

$P P_{t}=\partial+\gamma \widehat{S P D_{t}}+\varepsilon$

Where :

$P P t=$ Local government expenditure

$\left(\widehat{S P D_{t}}\right)=$ Estimation result Ratio of MSMEs tax revenue to total local tax revenue of Bandung City

$\varepsilon=$ error term

\section{RESULTS AND DISCUSSION}

\section{a. Tax Compliance, Tax Receipt of MSMEs, Fund Revenue Sharing.}

Based on the researcher's justification, the rate of compliance is still below $50 \%$. However, the rate of compliance in paying income tax is slowly increasing from year to year, averaging 2.6 percent per year.

In graphical form can be seen as follows:

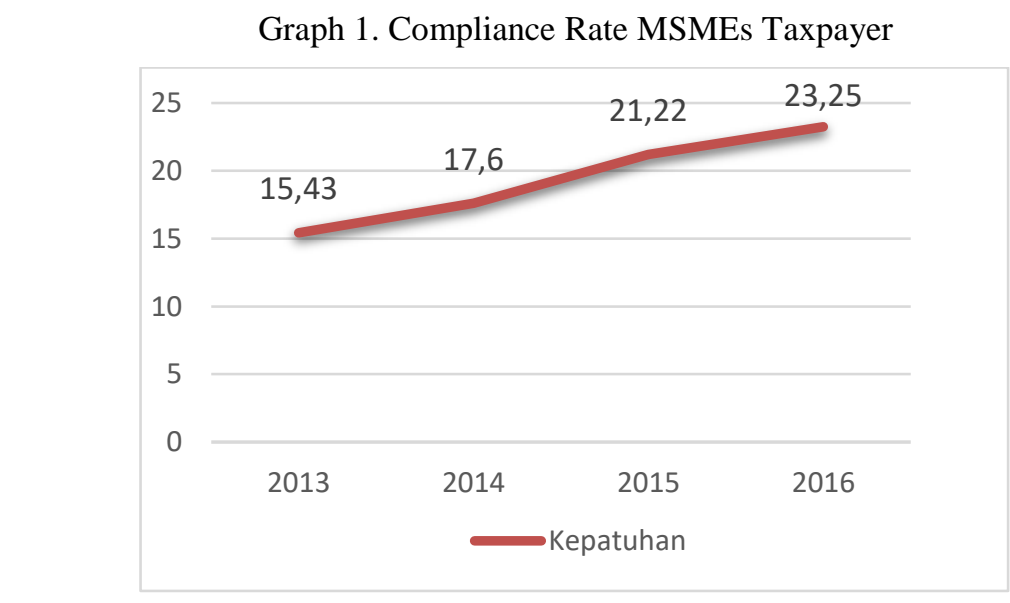

reprocessed.

Source : Regional Office of DGT West Java 1 (2017),

The potential of MSMEs to pay taxes can be seen from the average compliance rate is steadily increasing from 2013 to 2016, which is an the average was increase of up to 2.6 $\%$. This low rate of compliance, because not all MSMEs listed as taxpayers have the knowledge and procedures for calculating the taxes to be paid and most small taxpayers do not have a bookkeeping of the transactions was conducted as a basis for the determining taxes to be paid. Their backgrounds are partially unfunded with the books. 
In terms of understanding taxation rules becomes a complicated issue for low-income taxpayers. In terms of understanding taxation rules becomes a complicated issue for lowincome taxpayers. (Widodo, 2010). One's perception of imposing a final $1 \%$ tax rate by some small enterprise actors is considered to be quite burdensome to fulfill the obligation to pay taxes. Given the gross income is not proportional to the amount of tax paid, so the need to apply the principle of fairness in setting tax rates.

While final tax revenue in Bandung from 2013 until 2016 increased significantly. The increase can be seen in the graphical form as follows :

Graph 2. Final Tax Receipt MSMEs Bandung

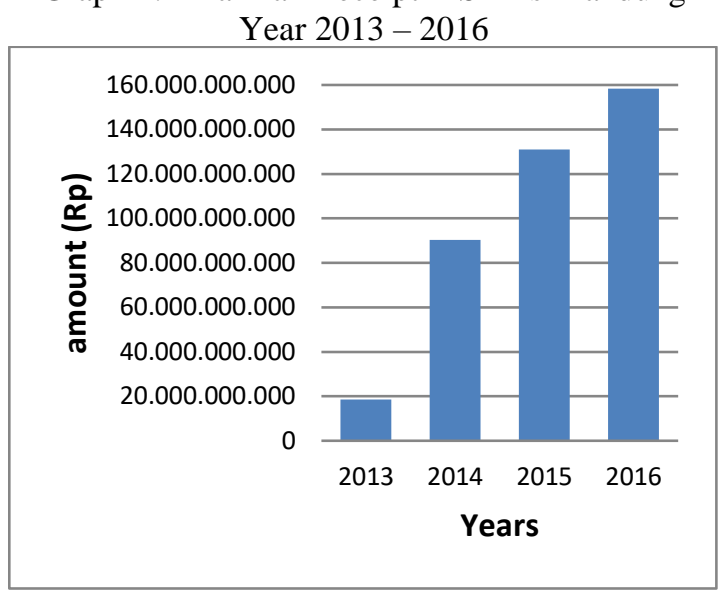

(2018), reprocessed.

Source: Regional Office of DGT West Java 1

The Balancing Fund is the local tax revenue from income tax returns received by Bandung local government from the central of the government. The Regional tax revenues from 2013 to 2016 tend to increase, only in 2015 decreased. The decline in local tax revenue according to the Head of the Tax Service City of Bandung caused by the decline in public purchasing power and targets set too high

In the form of graphs, the Fund Revenue Sharing as follows:

Graph 3. Fund Revenue Sharing Bandung

Year $2013-2016$

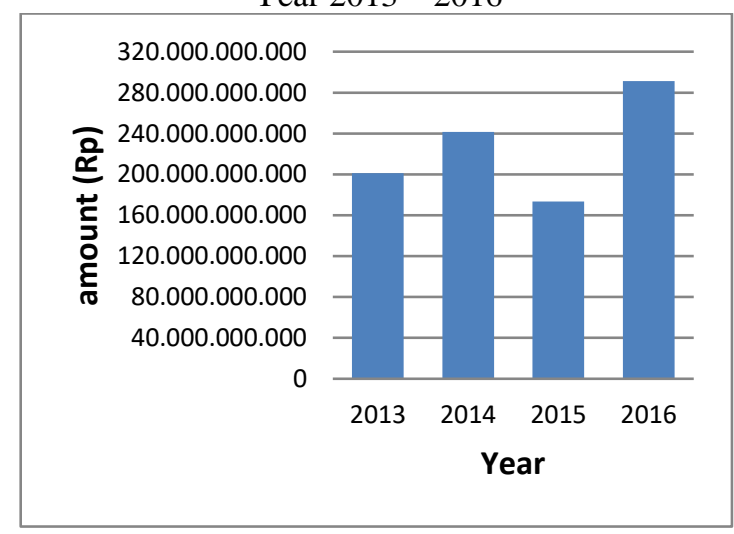

Source: APBD (2018), reprocessed

Increased tax revenue of MSMEs in Bandung, illustrates that small and medium enterprise actors gradually increasingly aware and the perceived benefits to fulfill their 88 | The International Journal of Business Review (The Jobs Review) Vol.1 | No.1 | 2018 
obligations as taxpayers, the efforts of Regional Office of Directorate General of Taxation West Java 1 to extend the taxpayer by increasing the number of registered taxpayers and the expansion of tax objects in the administration of the Directorate General of Taxation. The implication of the increase of final tax revenue of MSMEs is to improve its compliance ratio.

The balance of tax-sharing funds derived from State Expenditure Budget revenues allocated to the region to fund the needs of the region has increased from 2013 until 2016. This shows the GRDP of Bandung increased through increased local tax revenue from profitsharing received from the central government, thus reflecting the efforts of Bandung municipal government to carry out the activities of local tax management in the sector of MSMEs covering the potential data of their enterprise, subject and object of final tax of MSMEs.

\section{b. Compliance of Micro Enterprise Local Tax Payers to Gross Regional Domestic Product.}

\section{Regression Estimation Results}

The result of regression model estimation equation 1 shows that the variable of compliance has a significant effect to the ratio of income of MSMEs income tax with local tax revenue.

Table 1. Estimation Regression Result Equation 1

\begin{tabular}{lcccc}
\cline { 2 - 4 } & SPD & Coefficient & $\mathbf{t}$ & P> (t) \\
\cline { 2 - 4 } & KWP & $0.789323 * * *$ & 4.785166 & 0.0003 \\
Constanta & $-2.500158 * * *$ & -3.089597 & 0.0080 \\
\cline { 2 - 4 } & Probability > $=0.000291$ & \\
*** Significant at 1\% confidence rate & & \\
** Significant at 5\% confidence rate & & \\
* Significant at 10\% confidence rate & &
\end{tabular}

The regression model equation estimation result 2 shows that the variable of local tax revenues that have been influenced by the compliance of taxpayer of MSMEs have significant influence to local government expenditure of Bandung significantly.

Table 2. Estimation Regression Results Equation 2

\begin{tabular}{lrcc}
\hline $\mathbf{P P}$ & Coefficient & $\mathbf{t}$ & $\mathbf{P}>\mathbf{( t )}$ \\
\hline$\widehat{S P D_{t}}$ & $1259458 * * *$ & 36.0114 & 0.0000 \\
Constanta & $4030920 * * *$ & 79.0207 & 0.0000
\end{tabular}

Probability $>=0.000291$

*** Sgnificant at $1 \%$ confidence rate

** Significant at $5 \%$ confidence rate

* Significant at $10 \%$ confidence rate

The amount of the income taxes MSMEs earnings can be measured or seen by rate taxpayer compliance in carrying out its tax obligations. Increased compliance and the amount of income tax on MSMEs in Bandung from the year 2013 to 2016 was continue to increase, although still not reached the target set by the local government. While the acceptance Bandung through the balance of revenue sharing for the year 2013 - 2016 also

89 | The International Journal of Business Review (The Jobs Review) Vol.1 | No.2 |2018 
increased, only in 2015 that was decreased. The increasing taxpayer compliance rates can increase the amount of income tax on MSMEs income and have implications for increasing local revenue. This is in line with the results of the research was conducted by Restu Apriani et al. (2018), where the results of her this research was indicate that increased taxpayer compliance and tax collection can increase local tax revenues.

MSMEs income tax has a reduced income MSMEs. On the other hand, the government revenue from income tax of MSMEs increases and implies on the ability of the local government in financing the development of Bandung city including the empowerment of MSMEs. The empowerment of MSMEs through the programs of Cooperatives and MSMEs of Bandung provide benefits for small and medium enterprise actors, including: training, counseling or guidance, technology guidance. In addition, the efforts from the government Bandung city in 2016 has opened the Little Bandung was store in Malaysia and in 2017 in the South Korea with the aim to promote the work products with the small and medium enterprise actors in the order to develop their enterprise that can compete in the global market to increase productivity. The various programs mentioned above, is the local government expenditure of Bandung as a feedback to MSMEs in order to improve MSMEs productivity. The efforts to encourage the productivity of MSMEs actors have an impact on the rate of community welfare, especially for the perpetrators MSMEs. This is in the line with the results of research Magdalena et al.(2016).

Increased the productivity will have an impact on

increase in tax revenue and the ability of MSMEs to pay taxes. Thus, local government revenue from MSMEs income tax can increase the GRDP and local government expenditure of Bandung. However, the results of Azzam, et al. (2018), in the macro study show that the government expenditures have no significant effect on the economic growth of regency / municipality in the West Java Province. The difference of this result is possible not included the influence of taxpayer compliance of MSMEs in the variable of regional acceptance as the determinant variable of government expenditure. The results of this study are in the line and also supported by Nining Sudiyarti, el al. (2017), which shows that MSMEs have an effect on economic growth.

\section{CONCLUSION}

The compliance of MSMEs will affect the increase of Gross Regional Domestic Product through increasing the government expenditure from local tax revenue. Increased the government expenditure is used to increase the various government assistance programs as a feedback to MSMEs in order to increase productivity, so that in the end can increase incomes of MSMEs. Subsequent research is expected to be able to study and examine the compulsory income tax compliance of MSMEs against Gross Regional Domestic Product based on Government Regulation No 23 of 2018.

\section{REFERENCES}

Azzam Farras Wijdan, (2018). Analisis Pengaruh Pengeluaran Pemerintah, Investasi, Dana ZIS dan Tenaga Kerja Terhadap Pertumbuhan Ekonomi, in West Java Province, International Organization of

Scientific Research (IQSR) Journal, ISSN 2320-7388, Vol 1, Issue 5, Version VI. 
Darmayuda, Ufira Isbah and Eka Aranas Pailis, (2009). Pengaruh Bagi Hasil Pajak dan Bagi Hasil SDA Terhadap PDRB kabupaten/ kota Sumatera Utara, Journal of Economics, volume 17 No. 2

Magdalena Silawati Samosir, Made Suyana Utama, AA.IN.Marhaeni.(2016). Analisis Pengaruh Pemberdayaan dan Kinerja UMKM terhadap kesejahteraan pelaku UMKM, E- Journal Ekonomi dan Bisnis, ISSN : 2337-3067.

Minister of Finance Regulation No.174/PMK-07/2007, On The Temporary Allocation of Tax Sharing Funds Article 25 and article 29 Individual Tax Payers In The State and Tax Laws article 21

Nining Sudiyarti, Ismawati and Agus Irwansyah, (2017). Pengaruh UMKM Terhadap Pertumbuhan Ekonomi Daerah, Kabupaten Sumbawa, Journal of Economics and Business, Volume 14, No. 2, August

Restu Apriani, Mukhlizul Hamdi, Herawati, (2018). PengaruhKepatuhan Wajib Pajak, Pemeriksaan Wajib Pajak dan Pemungutan Pajak Terhadap Penerimaan Pajak Daerah, E Journal, Vol. 12, No.1.

Roger E. Back House. (2015). Revisiting Samuelson's Foundation of Economic Analysis, American Economic Ass, Journal of Economic Literature, Vol. 53, No, 2, (pp 326 350)

The Government Regulation of the Republic of Indonesia Number 46 of 2013, Income Tax on Income from Enterprise Received Or Obtained by Taxpayers Who Have Certain Gross Distributions.

Widodo, Widi, Deddy Djefris, Eka Aryani Wardhani, (2010). Moral, Budaya dan Kepatuhan Pajak, Alfabeta Bandung, 2010.

Wooldridge, Jeffrey M., (2010). Introductory Econometrics: A Modern Approach, Fourth Ed., South Western Cengeage Learning, Canada. 